\title{
Hydrochemical evaluation of river Ajali water for irrigational application in agricultural farmland
}

\author{
Hillary Onyeka Abugu ${ }^{1}$ (1) Pamela Favour Egwuonwu ${ }^{1}$. Janefrances Ngozi Ihedioha ${ }^{1} \cdot$ Nwachukwu Romanus Ekere $^{1}$
}

Received: 22 September 2020 / Accepted: 23 March 2021 / Published online: 8 April 2021

(c) The Author(s) 2021

\begin{abstract}
A major population of Udi and Ezeagu communities residing along river Ajali is peasant farmers who engage in the cultivation of vegetables along the river banks during the dry seasons. The existence of beverage industries around the 9th Mile Corner Ngwo of Enugu State has caused both communities to suffer from a shortage of quality drinking water, due to the constant discharge of wastewater by these industries into the Ajali River, which flows through these communities. Ajali River water near some beverage industries was then assessed for irrigation application. Water samples were collected from different locations along the river. Physicochemical and ionic parameters were analyzed using standard methods. Irrigation water criteria were applied, and the result showed that the major cation and anions were $\mathrm{Mg}^{2+}, \mathrm{Ca}^{2+}, \mathrm{Na}^{+}, \mathrm{K}^{+}$ and $\mathrm{HCO}_{3}{ }^{-}, \mathrm{SO}_{4}{ }^{2-}, \mathrm{PO}_{4}^{3-}, \mathrm{NO}_{3}^{-}, \mathrm{Cl}^{-}, \mathrm{CO}_{3}{ }^{-} \cdot \mathrm{Na}^{+}$was dominant with $43 \%$ average contribution of all the cations, while the least was $\mathrm{Mg}^{2+}$ with $4 \%$ average contribution; $\mathrm{HCO}_{3}{ }^{-}$was the dominant anion with $31 \%$ contribution while $\mathrm{PO}_{4}^{3-}$ was the least with $2 \%$ average contribution. The trend of the cations was $\mathrm{Na}^{+}>\mathrm{K}^{+}>\mathrm{Ca}^{2+}>\mathrm{Mg}^{2+}$ while the anions were $\mathrm{HCO}_{3}{ }^{-}>\mathrm{SO}_{4}{ }^{2-}>\mathrm{Cl}^{-}>\mathrm{NO}_{3}{ }^{-}>\mathrm{CO}_{3}{ }^{-}>\mathrm{PO}_{4}{ }^{3-}$. The cation concentrations were within $\mathrm{FAO}$ irrigation water specifications. However, some samples recorded higher values of carbonate above FAO limit (0-3 mg/L). All the irrigation assessment criteria suggested that Ajali River water is suitable for irrigation purposes.
\end{abstract}

Keywords Irrigation $\cdot$ Ajali $\cdot$ Cations $\cdot$ Anions $\cdot$ Piper diagram $\cdot$ Wilcox diagram

\section{Introduction}

In agricultural activities, water is an essential component that is supplied by rainfall or irrigational channels. Lakes, springs, and rivers are sources of irrigation water that are faced with pollution challenges. Water sources for agricultural purposes may be of poor quality resulting from natural or anthropogenic contamination or even both (Salifu et al. 2017). Ajali River may be polluted due to the effluents being discharged into it by brewery and beverages industries around the river (Atama et al. 2005; Egwuonwu et al. 2012; Ogbu et al. 2016), and poor water quality of rivers and other water bodies has an influence on agricultural products output quality. In the last decades, water bodies have been polluted

Hillary Onyeka Abugu

hillary.abugu@unn.edu.ng

Janefrances Ngozi Ihedioha

janefrances.ihedioha@unn.edu.ng

1 Department of Pure and Industrial Chemistry, University of Nigeria, Nsukka, Nigeria to the extent that some of them could no longer be applied in agricultural land (Simsek and Gunduz 2007; FAO/UN 2017). Ajali River flows dendrically, traversing Ogwofia Owa, Imezi Owa, and joined river Niger through Anambra River (Aniebone 2014).

The healthiness of river water is evaluated by several biological, chemical, and physical parameters (APHA 2005; Omer 2019). Chemical and physical characteristics of water are mostly considered in the evaluation of irrigation water quality. The measure of salinity, electrical conductivity, sodium, chloride, borate, sulfate and nitrate, residual sodium carbonate and trace elements' ( $\mathrm{Fe}, \mathrm{Mn}, \mathrm{Zn}, \mathrm{Cu}, \mathrm{Pb}, \mathrm{Cd}, \mathrm{Cr}$, $\mathrm{Ni}$ and $\mathrm{F}$ ) toxicity in water are some of the parameters used to evaluate water for irrigation purposes (Bauder et al. 2014).

The evaluation of water for irrigation application is largely dependent on the fate of certain minerals in the water, soil, and plants (Wilcox 1958). The osmotic and specific salinity are the different consequences of salinity on crops. Reduction in osmotic potential of the soil solution also reduces water flow from soil to root, if there is no corresponding reduction in root water potential, thereby 
preventing uptake of water by plants leading to a decrease in crop growth (Mandal et al. 2019). The specific consequence could be through nutrition and toxicity (Sonneveld and Voogt 2009). Nutritional disorders resulting from salinity could emanate from its effect on competitive uptake, nutrient availability and transport within the plant (Grattan and Grieve 1999; Fageria et al. 2011). Decreased nitrogen uptake under saline conditions has been due to interaction of $\mathrm{NO}_{3}{ }^{-}$and $\mathrm{Cl}^{-}$(Bar et al. 1997; Fuertes-Mendizábal et al. 2020) and $\mathrm{Na}^{+}$and $\mathrm{NH}_{4}{ }^{+}$(Rozeff 1995; FuertesMendizábal et al. 2020). Nutrient inefficiencies in plants may also come from high concentrations of sodium ion in the soil which decreases the concentration of the available magnesium, potassium and calcium ions (Asch et al. 2000; Hu and Schmidhalter 2005). According to Bernstein (1980); Mahmoud et al. (2020), salt sensitivity in citrus was partly related to the specific toxic effects of accumulation of $\mathrm{Cl}^{-}, \mathrm{Na}^{+}, \mathrm{B}$ and other ions in leaves, in addition to osmotic stress. Calcium ion, on the other hand, produced both direct and indirect effects by mitigating specific salinity effects (Cramer 2002; Shabala and Cuin 2008).

Southeastern Nigeria, of which Ezeagu and Udi in Enugu state are located, has two clear seasons (the rainy and dry seasons). Major population of these communities along river Ajali is peasant farmers who engage in the cultivation of vegetables along the river banks during the dry seasons. The existence of beverage industries around the 9th Mile Corner Ngwo of Enugu State has caused communities both in Udi and Ezeagu in Enugu State to suffer from a shortage of quality drinking water, due to the constant discharge of wastewater by these industries into the Ajali River, which flows through these communities. Egwuonwu et al. (2012) reported the impact of Nigerian brewery effluents on river Ajali and concluded that physicochemical parameters of Ajali River were within standards. Ogbu et al. (2016) reported the physicochemical and microbiological characteristics of Ama brewery effluent, and it is receiving Ajali River in Udi, Enugu State Nigeria, and observed that it was slightly impaired. Imo et al. (2017) reviewed the effects of brewery effluents on the quality of surface water in Nigeria and advised that the wastes should be effectively treated and properly managed, as the general physicochemical results reviewed showed that there were slight irregularities and inconsistencies in the effective management of the industries effluent discharges. However, the impacts of these industries were considered without consideration to the hydrochemical facies of Ajali River water for irrigation purposes. We therefore report the comprehensive hydrochemical evaluation of the river for its suitability in irrigating vegetable farms along its banks using permeability index according to Doneen (1964) which predicts the soil permeability. Soluble sodium percent is used to assess sodium hazard, Kelly's ratio (Kelly 1963), magnesium adsorption ratio (MAR) based on magnesium and calcium effects, residual sodium carbonate (RSC) or residual alkalinity (RA) by Richards (1954), chloro-alkaline indices (CAI) and the sodium adsorption ratio (SAR) which indicates the level to which irrigation water undergoes cation exchange reaction in the soil.

\section{Experimental}

\section{Study area}

The study was conducted in River Ajali, along its axis in Udi and Ezeagu Enugu State. River Ajali is a stream of running water moving to a lower level channel on land along Umumba village in Ezeagu local government area through Aguobu-owa village to Ameke Ngwo, Udi local government area in Enugu state (Fig. 1). Ezeagu is a local government area with its headquarters in Aguobu-Owa. Its coordinate is $6^{\circ} 25^{\prime} \mathrm{N}$ and $7^{\circ} 15^{\prime} \mathrm{E}$, which covers an area of about $633 \mathrm{~km}^{2}$ with a population of about 169,718 people according to 2006 Nigerian census. Udi is also a local government area on a coordinates of $6^{\circ} 19^{\prime} \mathrm{N}$ and $7^{\circ} 26^{\prime} \mathrm{E}$, covering 897 $\mathrm{km}^{2}$ with a population of 234,002 people. Along this axis are situated three beverage companies, namely Seven Up bottling company (A), Coca Cola bottling company (B) and Nigeria breweries (C). The rural dwellers from the villages and towns along this axis use this water for cooking, bathing, washing, drinking and irrigation applications.

The Ajali River Aguobu-Umumba watershed is predominantly underlain by Ajali and Nsukka Formations at upland and Mamu Formations in the lowlands. The poorly sorted Ajali sandstones are easily washed away by concentrated runoff from prolonged and torrential rainfall. The soil of the study area is sandy with small percentage of silt/clay (Nweke 2015). The underlying geology is predominantly sandstone (Ajali sandstone formation and Nsukka formation that is, Upper Coal Measures). The lithology of Nsukka formation is mainly interbedded shales, siltstones shale, sandy shale and thin coal seams, which have become lateralized in many places where they characteristically form resistant capping on mesas and buttes (Akande et al. 2007). The Ajali sandstone formation is considered a good aquifer, and there is existing groundwater exploitation.

\section{Sampling}

A total of thirty-three (33) water samples were collected (Table 1) comprising of three water samples from each point in an interval of one month (between December and February 2019). The samples were collected with a clean two liter screw capped polyethylene container, which was thoroughly washed, rinsed with analytical grade $1: 1 \mathrm{HCl}$ and then rinsed with distilled water. At the point of water 


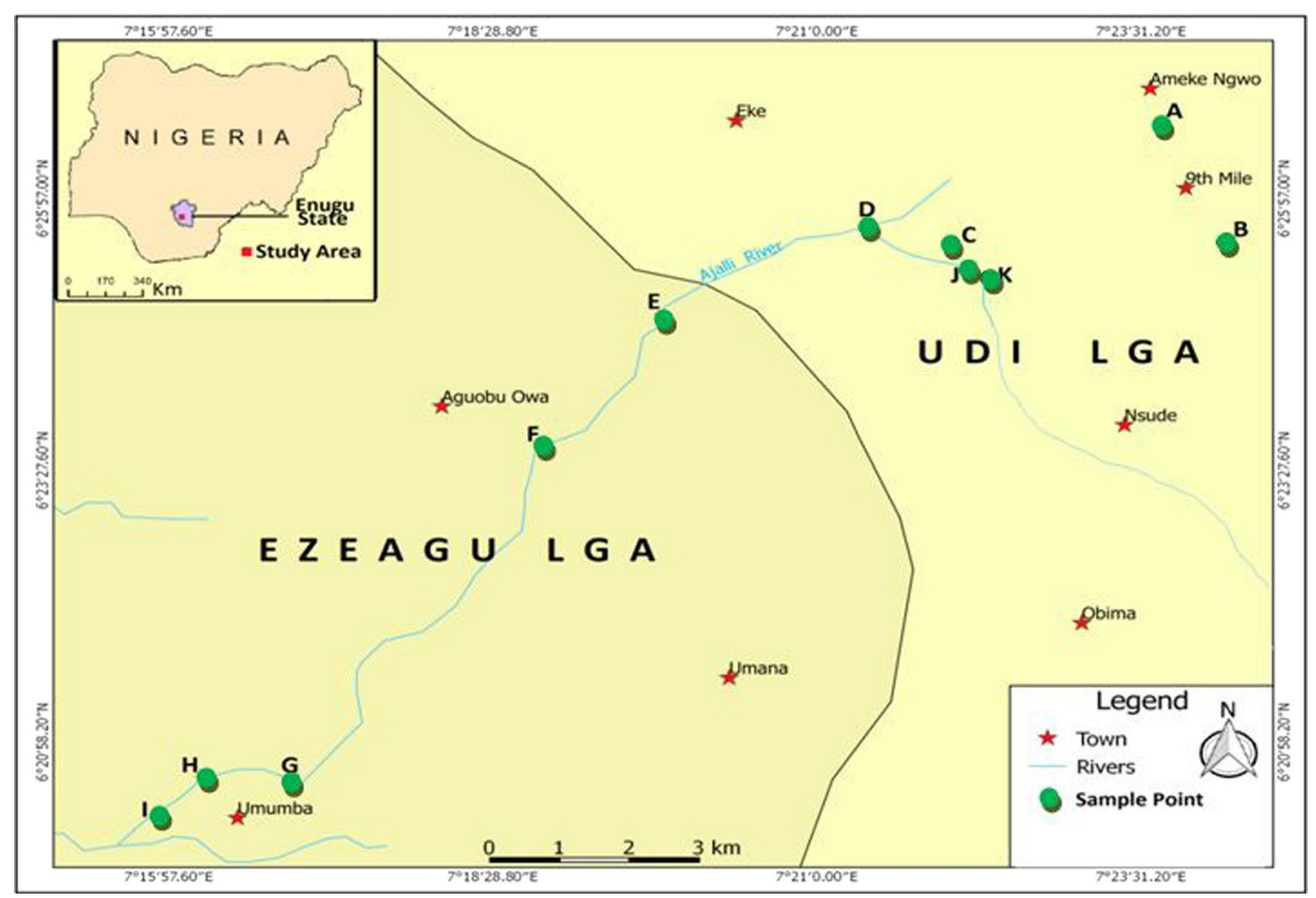

Fig. 1 Map of the study area

Table 1 Sample points and their coordinates

\begin{tabular}{|c|c|c|c|}
\hline \multirow[t]{2}{*}{ Sample point } & \multicolumn{2}{|l|}{ Coordinates } & \multirow[t]{2}{*}{ Description of sampling point } \\
\hline & $\mathrm{s}$ & Longitude (E) & \\
\hline A & $6^{\circ} 26^{\prime} 35.629^{\prime \prime} \mathrm{N}$ & $7^{\circ} 23^{\prime} 43.428^{\prime \prime} \mathrm{E}$ & Effluent discharge point of Industry A \\
\hline B & $6^{\circ} 25^{\prime} 30.319^{\prime \prime} \mathrm{N}$ & $7^{\circ} 24^{\prime} 12.335^{\prime \prime} \mathrm{E}$ & Effluent discharge point of industry B \\
\hline $\mathrm{C}$ & $6^{\circ} 25^{\prime} 30.320^{\prime \prime} \mathrm{N}$ & $7^{\circ} 22^{\prime} 07.070^{\prime \prime} \mathrm{E}$ & Effluent discharge point for Industry C \\
\hline $\mathrm{D}$ & $6^{\circ} 25^{\prime} 39.956^{\prime \prime} \mathrm{N}$ & $7^{\circ} 21^{\prime} 23.174^{\prime \prime} \mathrm{E}$ & Effluent entry point of $\mathrm{A}, \mathrm{B}$ and $\mathrm{C}$ industries \\
\hline $\mathrm{E}$ & $6^{\circ} 24^{\prime} 48.565^{\prime \prime} \mathrm{N}$ & $7^{\circ} 19^{\prime} 46.816^{\prime \prime} \mathrm{E}$ & $30 \mathrm{~m}$ from the effluents entry points surrounded by farmland \\
\hline $\mathrm{F}$ & $6^{\circ} 23^{\prime} 36.832^{\prime \prime} \mathrm{N}$ & $7^{\circ} 18^{\prime} 50.072^{\prime \prime} \mathrm{E}$ & $60 \mathrm{~m}$ from the effluents entry point surrounded by bushes \\
\hline G & $6^{\circ} 20^{\prime} 34.822^{\prime \prime} \mathrm{N}$ & $7^{\circ} 16^{\prime} 56.584^{\prime \prime} \mathrm{E}$ & $\begin{array}{l}\text { Ajali water around Umumba community in Ezeagu where activities like washing } \\
\text { of cloth, food substances (cassava), motor-cycles and farmlands around the river }\end{array}$ \\
\hline $\mathrm{H}$ & $6^{\circ} 20^{\prime} 36.964^{\prime \prime} \mathrm{N}$ & $7^{\circ} 16^{\prime} 15.899^{\prime \prime} \mathrm{E}$ & $30 \mathrm{~m}$ from sampling point $\mathrm{G}$ down the river along Umumba community in Ezeagu \\
\hline I & $6^{\circ} 20^{\prime} 13.410^{\prime \prime} \mathrm{N}$ & $7^{\circ} 15^{\prime} 53.416^{\prime \prime} \mathrm{E}$ & $30 \mathrm{~m}$ from sampling point $\mathrm{H}$ down the river along Umumba community in Ezeagu \\
\hline $\mathrm{J}$ & $6^{\circ} 25^{\prime} 13.1896^{\prime \prime} \mathrm{N}$ & $7^{\circ} 22^{\prime} 10.282^{\prime \prime} \mathrm{E}$ & Before the entry point of the wastewater into Ajali \\
\hline $\mathrm{K}$ & $6^{\circ} 25^{\prime} 11.0483^{\prime \prime} \mathrm{N}$ & $7^{\circ} 22^{\prime} 17.7767^{\prime \prime} \mathrm{E}$ & Before the entry point of the wastewater into Ajali \\
\hline
\end{tabular}

collection, the polyethylene containers were rinsed three times with the water samples. The polyethylenes were completely filled to capacity, and temperature and $\mathrm{pH}$ were taken immediately on the spot. The samples were then transported to the laboratory ice-cooled and stored in a refrigerator at $4{ }^{\circ} \mathrm{C}$ pending the determination of other parameters.

\section{Physicochemical parameters}

Total dissolved solids (TDS), turbidity, total suspended solids (TSS), sulfate, nitrates, phosphate, conductivity, total alkalinity and total hardness were analyzed according to APHA (2005) standard methods. 


\section{On-site analysis}

On-site analyses of $\mathrm{pH}$, conductivity, temperature and TDS were carried out at point of sample collection with calibrated (Hanna model HI-8733) pH meter, conductivity and temperature/TDS meter (model TDS-3) instruments, respectively.

\section{Off-site analysis}

$\mathrm{Na}^{+}$and $\mathrm{K}^{+}$concentrations were determined using flame photometer (Jenway PFP7/PFP7/C model), and $\mathrm{Ca}^{2+}$ and $\mathrm{Mg}^{2+}$ concentrations were measured using complexometric titration of EDTA solution in line with the standard procedure according to Tucker and Kurtz (1961). In the determination of $\mathrm{HCO}_{3}{ }^{-}$and $\mathrm{Cl}^{-}$, potentiometric and argentometric titration procedures were applied, respectively (APHA 1992), while $\mathrm{NO}_{3}{ }^{-}, \mathrm{SO}_{4}{ }^{2-}$ and $\mathrm{PO}_{4}{ }^{3-}$ were measured using UV-visible spectrophotometer (Beckman DU640 model) in line with APHA (1992) and Ramesh and Anbu (1996) procedure. Triplicate analysis of each parameter was carried out, and the mean value is presented in Table 2.

\section{Water quality assessment for irrigation purposes}

In the evaluation for usability of Ajali River water for irrigation, the following water quality indices were used:

1. Permeability index (PI) according to Doneen (1964) is given in Eq. 1:

$$
\mathrm{PI}=\left(\left(\mathrm{Na}^{+}+\sqrt{ } \mathrm{HCO}_{3}^{-}\right) / \mathrm{Na}^{+}+\mathrm{Mg}^{2+}+\mathrm{Ca}^{2+}\right) \times 100
$$

2. Soluble sodium percent (SSP) is used to assess sodium hazard. According to Doneen (1964) SSP is given in Eq. 2:

$$
\mathrm{SSP}=\frac{\mathrm{Na}^{+}+\mathrm{K}^{+}}{\mathrm{Na}^{+}+\mathrm{Ca}^{2+}+\mathrm{Mg}^{2+}+\mathrm{K}^{+}} \times 100
$$

SSP above $60 \%$ is not desirable in water for irrigation since it could lead to sodium accumulations which can cause a breakdown in the physical properties of the soil.

3. Kelly (1963) defined irrigation water according to Kelly's ratio as given in Eq. 3:

$$
\mathrm{KR}=\mathrm{Na}^{+} /\left(\mathrm{Ca}^{2+}+\mathrm{Mg}^{2+}\right)
$$

4. Raghunath (1987) proposed magnesium adsorption ratio (MAR) for the classification of water for irrigation which is based on magnesium and calcium as shown in Eq. 4:

$$
\text { MAR }=\left(\mathrm{Mg}^{2+} /\left(\mathrm{Ca}^{2+}+\mathrm{Mg}^{2+}\right)\right) \times 100
$$

5. Residual sodium carbonate (RSC) or residual alkalinity (RA) by Eaton (1950) and Richards (1954) is also used to classify irrigation water.

$$
\mathrm{RSC}=\left(\mathrm{HCO}_{3}^{-}+\mathrm{CO}_{3}\right)-\left(\mathrm{Ca}^{2+}+\mathrm{Mg}^{2+}\right)
$$

6. Chloro-alkaline indices (CAI)

$$
\mathrm{CAI}=\frac{\mathrm{Cl}^{-}-\left(\mathrm{Na}^{+}+\mathrm{K}^{+}\right)}{\mathrm{Cl}^{-}}
$$

7. The sodium adsorption ratio (SAR) which indicates the level to which irrigation water undergoes cation exchange reaction in soil is given in Eq. 7 as proposed by ss:

$$
\mathrm{SAR}=\frac{\mathrm{Na}}{\sqrt{(\mathrm{Ca}+\mathrm{Mg}) / 2}}
$$

\section{Statistical analysis}

The correlations between the sample parameters were determined using Pearson's correlation at 0.01 and 0.05 significant levels, while the hierarchical cluster dendogram was used to assess the relationship between the parameters. All the statistical analyses were performed using SPSS version 16.0. Rockware Aq.QA, 1.5.0 was used to determine the water types, $\%$ difference of anion-cation balance and salinity hazard.

\section{Results and discussion}

The river water quality parameters are presented in Table 2 . The $\mathrm{pH}$ range showed a narrow variations (5.95 to 7.05) indicating slightly acidic to slightly alkaline water, which is within the limit for irrigation water (6.5-8.4) as set by FAO (1994). Kaur et al. (2016) reported comparable pH values within Malwa region, southwestern part of Punjab, India. Ahmedov et al. (2018) reported a higher $\mathrm{pH}$ with a mean value of 8.46 in different rivers of Azerbaijan. Irrigation water with $\mathrm{pH}$ value above the range has been reported to cause nutritional imbalance in the plants (FAO 1994). The $\mathrm{pH}$ values of samples (A, B and C) closer to the industries' effluent discharge points indicated that the effluents from the industries may be alkaline. The alkalinity of the samples varied from 0.00 to $2.50 \mathrm{mg} / \mathrm{L}$. Water with appreciable alkalinity has the characteristics of reacting with its solute content and neutralize the acid depending on the nature of the soil and rock on which the water flows through. The total hardness of Ajali River water samples varied from 11.00 to 


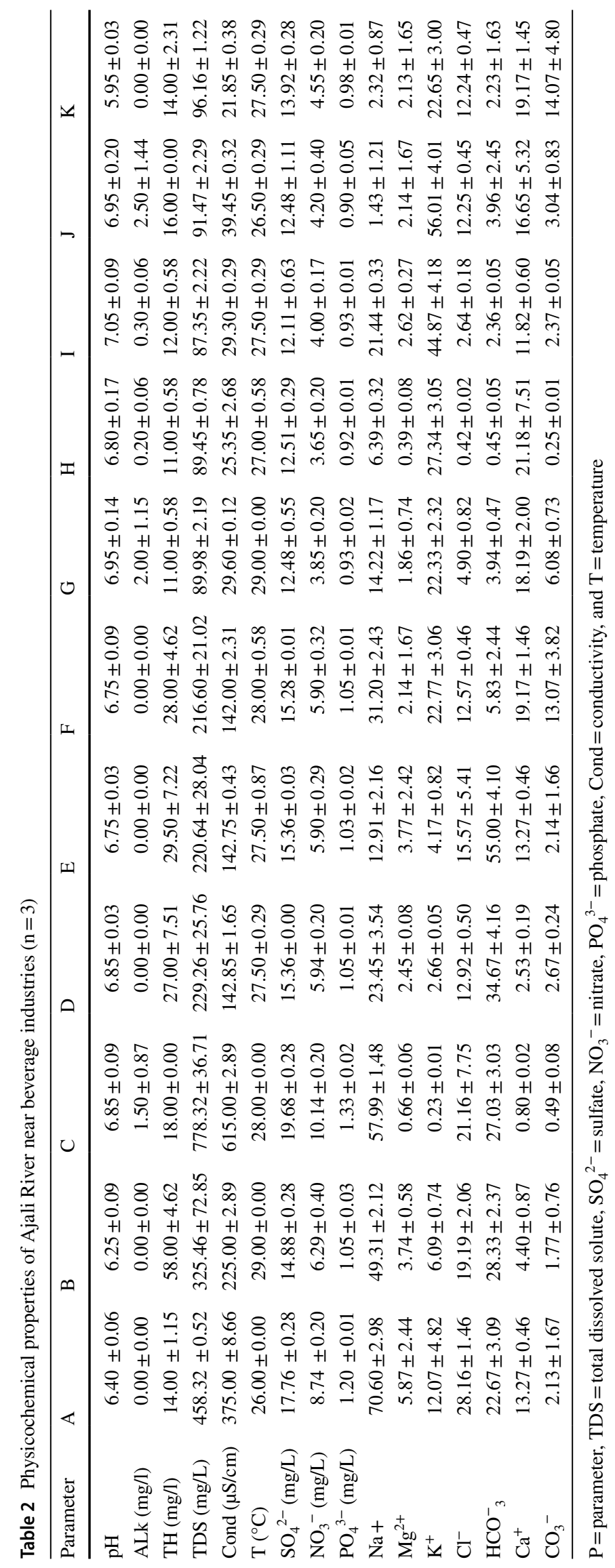


$58.00 \mathrm{mg} / \mathrm{L}$ which is within the FAO standard for irrigation water. The result obtained showed that the total hardness was less compared to earlier result (Kaur et al. 2016). According to Sawyer and McCarty (1967), the total hardness of all the samples was classified as soft ( $\leq 75 \mathrm{mg} / \mathrm{L})$. This indicates less water-rock interaction by the River. The TDS varied from 87.35 to 778.32 with a mean value of $243.91 \mathrm{mg} / \mathrm{L}$. All the Ajali River water samples had TDS within the FAO (1994) acceptable limit (600-1000 mg/L) for irrigation water. Freeze and Cherry (1979) classified water based on TDS concentration as fresh $(<1000 \mathrm{mg} / \mathrm{L})$, brackish $(>1000 \mathrm{mg} / \mathrm{L})$, saline $(>10,000 \mathrm{mg} / \mathrm{L})$ and brine $(1,000,000 \mathrm{mg} / \mathrm{L})$. On this basis, Ajali River water is freshwater indicating its suitability for irrigation purposes. Ahmedov et al. (2018) reported a higher TDS range of $166-4047 \mathrm{mg} / \mathrm{L}$ in Azerbaijan. The presence of dissolved ions in water is indicated by the electrical conductivity (EC) of the water, and it increases with increase in the ionic concentration. In this study, the EC ranged from 21.85 to 615 $\mu \mathrm{S} / \mathrm{cm}$ with an average value of $162.559 \mu \mathrm{S} / \mathrm{cm}$. Kaur et al. (2016) observed a wide variation in electrical conductivity (minimum value of $563.80 \mu \mathrm{S} / \mathrm{cm}$ and maximum value of $7007 \mu \mathrm{S} / \mathrm{cm}$ ) with an average value of $2016.36 \mu \mathrm{S} / \mathrm{cm}$ during summer season in Malwa region, southwestern part of Punjab, India. An irrigation water with EC of $3000 \mu \mathrm{S} / \mathrm{cm}$ or less is acceptable for irrigation application according FAO (1994), indicating that Ajali River water is, with respect to its EC, suitable for irrigation purpose. The sample's temperatures were within ambient indicating its suitability for irrigation application.

\section{Major ion chemistry}

The major cation and anions in Ajali River water were $\mathrm{Mg}^{2+}, \mathrm{Ca}^{2+}, \mathrm{Na}^{+}, \mathrm{K}^{+}$and $\mathrm{HCO}_{3}{ }^{-}, \mathrm{SO}_{4}{ }^{2-}, \mathrm{PO}_{4}{ }^{3-}, \mathrm{NO}_{3}{ }^{-}$, $\mathrm{Cl}^{-}, \mathrm{CO}_{3}^{-}$(Fig. 2A and 2B). Of all these cations, $\mathrm{Na}^{+}$was dominant with $43 \%$ contribution while the least was $\mathrm{Mg}^{2+}$ with $4 \%$ contribution. Bicarbonate was the dominant anion with $31 \%$ contribution while $\mathrm{PO}_{4}{ }^{3-}$ was the least with $2 \%$ average contribution. The order of abundance of the cations was $\mathrm{Na}^{+}>\mathrm{K}^{+}>\mathrm{Ca}^{2+}>\mathrm{Mg}^{2+}$ while the anions were
$\mathrm{HCO}_{3}{ }^{-}>\mathrm{SO}_{4}{ }^{2-}>\mathrm{Cl}^{-}>\mathrm{NO}_{3}{ }^{-}>\mathrm{CO}_{3}{ }^{-}>\mathrm{PO}_{4}{ }^{3-}$. Tiri et al. (2019) observed slightly different order of cations and anions abundance- $\mathrm{Ca}>\mathrm{Na}>\mathrm{Mg}>\mathrm{K}$ and $\mathrm{HCO}_{3}>\mathrm{Cl}>\mathrm{SO}_{4}>\mathrm{NO}_{3}$, respectively, in Koudiate Medouar dam water, Algeria.

The cations concentrations in all the samples were within FAO (1994) irrigation water specifications. However, the carbonate has the characteristics of reacting with its solute content and neutralize acid, resulting from the nature of the soil and rock on which it passes. The concentrations in samples F, G, J and $\mathrm{K}$ were above FAO limit of $0-3 \mathrm{mg} / \mathrm{L}$. These samples were collected near the entry point of the industrial wastewater into Ajali River and in communities where a lot of washing activities take place. High carbonate and bicarbonate in irrigation water are not desirable as it increases the sodium absorption ratio (SAR) index (Lenntech 1998). This results from the fact that bicarbonate and carbonate ions react with $\mathrm{Ca}$ and $\mathrm{Mg}$, thus precipitating $\mathrm{MgCO}_{3}$ or $\mathrm{CaCO}_{3}$ when the soil solution get concentrated in drying conditions. The concentration of $\mathrm{Ca}$ and $\mathrm{Mg}$ decreases relatively to sodium while the SAR index increases. This usually increases the alkalinity and $\mathrm{pH}$ of the water. Therefore, we can infer that the relatively alkaline $\mathrm{pH}$ values recorded in Ajali River water could be as a result of the higher carbonate and bicarbonates ions.

The weathering of silicate minerals contributes to the enrichment of these minerals (Cai et al. 2008). The weathering of rock involves silicate and carbonate minerals (Eq. 8 and 9).

$\mathrm{CaCO}_{3}+\mathrm{CO}_{2}+\mathrm{H}_{2} \mathrm{O}=\mathrm{Ca}^{2+}+2 \mathrm{HCO}_{3}^{-}$

$\mathrm{CaSiO}_{3}+2 \mathrm{CO}_{2}+3 \mathrm{H}_{2} \mathrm{O}=2 \mathrm{HCO}_{3}^{-}+\mathrm{Ca}^{2+}+\mathrm{H}_{4} \mathrm{SiO}_{4}$

Because of this, bicarbonates derived from silicate weathering are generated from the atmospheric and soil $\mathrm{CO}_{2}$ resulting from bacterial degradation of organic matter (like faeces) and plant root respiration (Cai et al. 2008).

$\mathrm{Na}$ and $\mathrm{K}$ values ranged from 1.43 to 70.6 and 0.23 to $56.01 \mathrm{mg} / \mathrm{L}$ with average values of 26.478 and $20.108 \mathrm{mg} / \mathrm{L}$, respectively (Table 3 ). Sodium in surface water is controlled
Fig. 2 Contribution of cations (a) and anions (b) to the total cationic and anionic balance
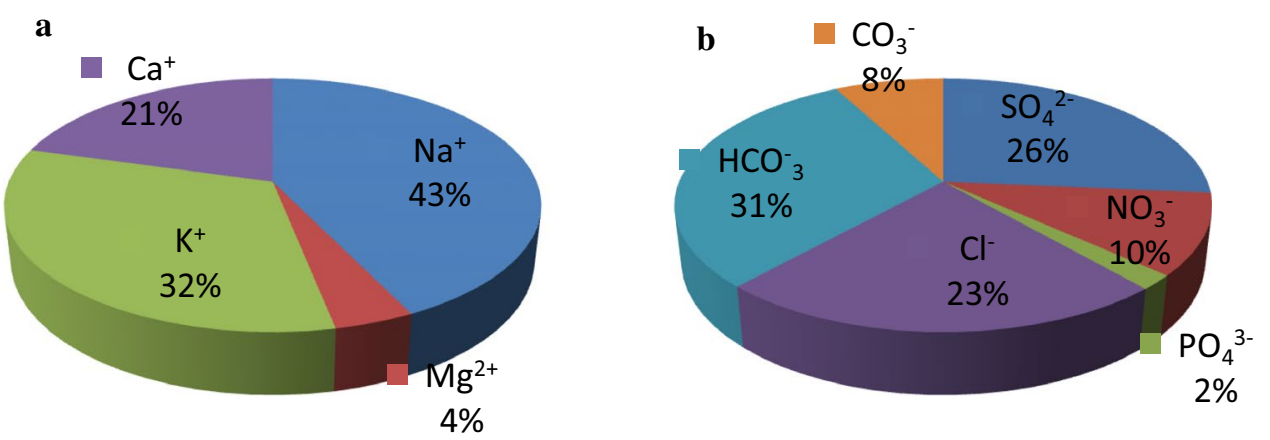
Table 3 Total mean concentration of physicochemical parameters and FAO standard for irrigation water

\begin{tabular}{lclll}
\hline Parameter & Total mean \pm SD & Max & Min & FAO \\
\hline $\mathrm{pH}$ & $6.686 \pm 0.94$ & 7.05 & 5.95 & $6.5-8.4$ \\
$\mathrm{ALk}(\mathrm{mg} / \mathrm{L})$ & $0.591 \pm 13.91$ & 2.5 & 0 & $\mathrm{NA}$ \\
$\mathrm{TH}(\mathrm{mg} / \mathrm{L})$ & $21.681 \pm 213.74$ & 58 & 11 & $200-500^{\mathrm{a}}$ \\
$\mathrm{TDS}(\mathrm{mg} / \mathrm{L})$ & $243.91 \pm 185.51$ & 778.32 & 87.35 & $600-1000^{\mathrm{a}}$ \\
$\mathrm{Cond} .(\mu \mathrm{S} / \mathrm{cm})$ & $162.559 \pm 0.92$ & 615 & 21.85 & 3000 \\
$\left.\mathrm{Temp}^{\circ} \mathrm{C}\right)$ & $27.591 \pm 2.39$ & 29 & 26 & NA \\
$\mathrm{SO}_{4}{ }^{2-}(\mathrm{mg} / \mathrm{L})$ & $14.711 \pm 2.09$ & 19.68 & 12.11 & $0-960$ \\
$\mathrm{NO}_{3}{ }^{-}(\mathrm{mg} / \mathrm{L})$ & $5.742 \pm 0.13$ & 10.14 & 3.65 & $0-10$ \\
$\mathrm{PO}_{4}{ }^{3-}(\mathrm{mg} / \mathrm{L})$ & $1.034 \pm 8.21$ & 1.33 & 0.9 & NA \\
$\mathrm{Na}^{+}(\mathrm{mg} / \mathrm{L})$ & $26.478 \pm 17.86$ & 70.6 & 1.43 & $0-920$ \\
$\mathrm{Mg}^{2+}(\mathrm{mg} / \mathrm{L})$ & $2.525 \pm 4.80$ & 5.87 & 0.39 & $0-60$ \\
$\mathrm{~K}^{+}(\mathrm{mg} / \mathrm{L})$ & $20.108 \pm 1.52$ & 56.01 & 0.23 & NA \\
$\mathrm{Cl}^{-}(\mathrm{mg} / \mathrm{L})$ & $12.911 \pm 17.85$ & 28.16 & 0.42 & $0-1065$ \\
$\mathrm{HCO}_{3}{ }^{-}(\mathrm{mg} / \mathrm{L})$ & $16.951 \pm 7.19$ & 55 & 0.45 & $0-610$ \\
$\mathrm{Ca}^{+}(\mathrm{mg} / \mathrm{L})$ & $12.768 \pm 23.38$ & 21.18 & 0.8 & $0-400$ \\
$\mathrm{CO}_{3}{ }^{-}(\mathrm{mg} / \mathrm{L})$ & $4.365 \pm 0.34$ & 14.07 & 0.25 & $0-3$ \\
\hline
\end{tabular}

$N A$ not available, $S D$ standard deviation

${ }^{\mathrm{a}}$ WHO (2006)

by the saline intrusions, evaporates and silicate minerals (Sajil et al. 2013). In Ajali River, the $\mathrm{Na}$ and $\mathrm{K}$ are generated from the rock weathering of the silicate. A relatively lower concentration of $\mathrm{Ca}$ than $\mathrm{Na}$ shows the effect of cation exchange between these minerals.

\section{Evaluation for Irrigation application}

There are several criteria that have been used to evaluate the suitability of water for irrigation purposes (Table 4).
Virtually, all the criteria are based on the total concentrations of soluble salts, relative proportion of sodium to other cations and chemical concentration of other ions (Michael, 1992). Figure 3 presents the PI of Ajali River water data taking into consideration the $\mathrm{Mg}^{2+}, \mathrm{Ca}^{2+}, \mathrm{Na}^{+}$and $\mathrm{HCO}_{3}{ }^{-}$concentration in the water. The prolonged use of water-rich ions affects the permeability of the soil (Singh et al. 2014). Doneen (1964) classified irrigation based on the PI into class I, II and III. Class I and II represent $75 \%$ maximum permeability which indicated that the water sample is suitable for irrigation, while PI of $25 \%$ maximum permeability or below is seen as unsuitable for irrigation application (Doneen 1964; Raju 2007). In this study, it was observed that $72.7 \%$ of the samples fell under class I and II, buttressing the Ajali River suitability for irrigation purposes. From Doneen diagram, three samples $(27.3 \%)$ were predicted to be under the unsuitable class, but permeability index calculation predicted samples A, B, C and D (samples from the industries effluent channels) to be under unsuitable zone. Higher levels of $\mathrm{HCO}_{3}{ }^{-}$and $\mathrm{Na}^{+}$ions were in direct relation to the PI which is due to the cation exchange and carbonate dissolution (Xu et al. 2019).

The Gibbs diagram is used to assay geochemical processes that control the sources of major ions in water which result from water reactions with the geologic materials on which it flows through (Li et al. 2016; Appelo and Postma 1996). The functional sources of the cation and anions were largely evaluated by plotting the samples in line with the variations in the ratio of $\mathrm{Na} /\left(\mathrm{Na}+\mathrm{Ca}\right.$ and $\mathrm{Cl} /\left(\mathrm{Cl}+\mathrm{HCO}_{3}\right)$ as a function of TDS (Gibbs 1970). Figure 4 shows three natural mechanisms (evaporation crystallization, rock and precipitation dominance) that control the water chemistry (Li et al. 2013; Wu et al. 2015). Ajali River water was found in the rock dominance zone (Fig. 4a), implying that weathering of
Table 4 Assessment of Ajali River water for irrigation purposes

\begin{tabular}{|c|c|c|c|c|c|c|c|}
\hline Sample code & PI & SSP & $\mathrm{KR}$ & MAR & RSC & CAI & SAR \\
\hline A & 83.97738 & 81.20028 & 3.68861 & 30.66876 & 5.66 & -1.93572 & 22.82174 \\
\hline B & 95.0959 & 87.18917 & 6.05774 & 45.94595 & 21.96 & -1.88692 & 24.44206 \\
\hline $\mathrm{C}$ & 106.2894 & 97.55362 & 39.71918 & 45.20548 & 26.06 & -1.75142 & 67.87216 \\
\hline $\mathrm{D}$ & 103.1942 & 83.98199 & 4.708835 & 49.19679 & 32.36 & -1.0209 & 14.86083 \\
\hline $\mathrm{E}$ & 67.86711 & 50.05862 & 0.757629 & 22.12441 & 40.1 & -0.09698 & 4.422893 \\
\hline $\mathrm{F}$ & 64.0155 & 71.69235 & 1.464101 & 10.04223 & -2.41 & -3.29356 & 9.558239 \\
\hline G & 47.28609 & 64.57597 & 0.709227 & 9.276808 & -10.03 & -6.45918 & 4.491148 \\
\hline $\mathrm{H}$ & 25.25329 & 60.99458 & 0.296245 & 1.808067 & -20.87 & -79.3095 & 1.945767 \\
\hline I & 64.03631 & 82.11765 & 1.484765 & 18.14404 & -9.78 & -24.1174 & 7.979142 \\
\hline $\mathrm{J}$ & 16.91382 & 75.35091 & 0.076104 & 11.38904 & -11.79 & -3.68898 & 0.466539 \\
\hline K & 16.14445 & 53.96585 & 0.10892 & 10 & -5 & -1.04003 & 0.710908 \\
\hline Mean & 62.73395 & 73.51645 & 5.370123 & 23.07287 & 6.023636 & -11.3273 & 14.50649 \\
\hline SD & 33.12986 & 14.77564 & 11.56892 & 17.02384 & 20.61813 & 23.53495 & 19.57081 \\
\hline Max & 106.2894 & 97.55362 & 39.71918 & 49.19679 & 40.1 & -0.09698 & 67.87216 \\
\hline Min & 16.14445 & 50.05862 & 0.076104 & 1.808067 & -20.87 & -79.3095 & 0.466539 \\
\hline
\end{tabular}




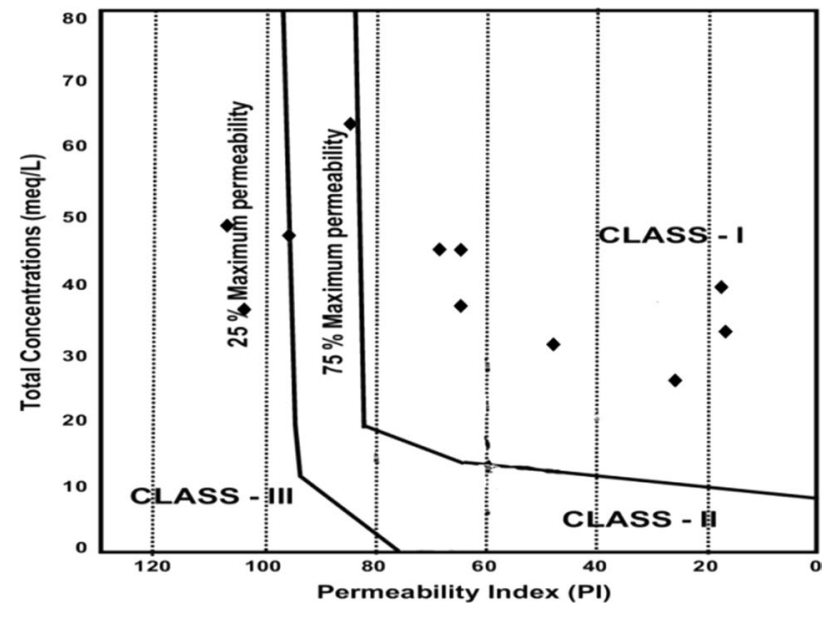

Fig. 3 Doneen diagram representing Ajali River water quality for irrigation application

rock by the water and leaching are the main processes affecting the water chemistry (Xu et al. 2019). A similar observation was made in Fig. $4 \mathrm{~b}$ in addition to the interaction between the chemistry of precipitation and the rock chemistry, indicating the samples ranging from freshwater to saline water (Sawis and Issa 2015). These observations could be due to the underlying geology in the study area which is predominantly sandstone (Ajali Sandstone formation and Nsukka formation, also called the Upper Coal Measures). The lithology of the Nsukka formation is mainly interbedded shales, siltstones shale, sandy shale and thin coal seams, which have become lateritized in many places where they characteristically form resistant capping on mesas and buttes (Akande et al. 2007).

Wilcox plot (Fig. 5), which relates the sodium percent and the electrical conductivity, was used to predict the suitability of water for irrigation purposes. In this study, all the samples collected from the eleven locations fell under the excellent to good quality for irrigation application. In terms of percent sodium-electrical conductivity, Ajali River water is suitable for irrigation purposes. The soluble sodium percent criteria classified samples A, B, C, D and I as unsuitable (> 80\%) which represent $45.45 \%$ of the total sample, sample F, G, H and $\mathrm{J}$ were doubtful (60-80\%) representing $36.36 \%$ while samples $\mathrm{E}$ and $\mathrm{K}$ representing $18.18 \%$ of the samples were permissible (Table 4).

Kelly's ratio (KR) is another criterion to evaluate the suitability of water for irrigation application. According to the calculation, it predicted Ajali River samples E, G, H, J and $\mathrm{K}(\mathrm{KR}<1)$ as suitable for irrigation and sample $\mathrm{A}, \mathrm{B}, \mathrm{C}$, $\mathrm{D}, \mathrm{F}$ and $\mathrm{I}$ as unsuitable $(\mathrm{KR}>1)$ for irrigation purposes representing $54.5 \%$ of the samples. The section of the Ajali River with KR $>1$ is those samples collected around the effluent channel of the industries indicating the effects of the industries effluents on the Ajali River. The magnesium adsorption ration (MAR) was also used to assess Ajali River, and it predicted all the samples to be within the acceptable limit (MAR < 50\%). MAR is based on the $\mathrm{Mg}$ and Ca concentration in water. According to Neina (2019); Raghunath (1987), high magnesium hazard value $>50 \%$ is detrimental to crop yield as it will make the soil more alkaline. Residual sodium carbonate (RSC) predicted all the Ajali River water samples to be suitable (RSC $<1.25 \mathrm{Meq} / \mathrm{L}$ ) for irrigation. Also, chloro-alkaline indices (CAI) criterion, which gives an account of the ion exchange between the water and rock, indicated that there is an ion exchange between $\mathrm{K}+\mathrm{Na}$ with $\mathrm{Mg}$ and $\mathrm{Ca}$. A positive $\mathrm{CAI}$ value shows that there is no ion exchange. Sodium absorption ratio (SAR) predicts the sodium hazards, which reduces soil permeability and inhibits water absorption by the crops (Tahmasebi et al. 2018). SAR classifies water as excellent $(\mathrm{SAR}<10)$, good (SAR
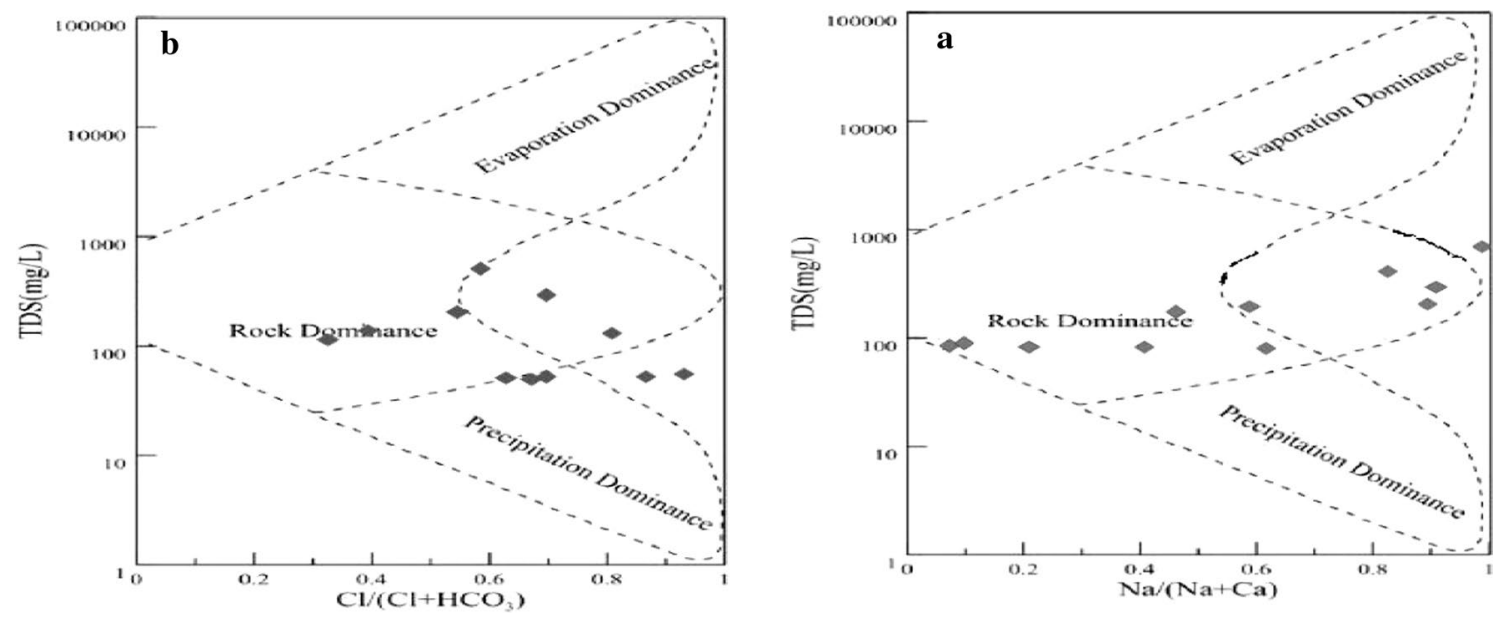

Fig. 4 Gibbs (1970), diagram showing the Ajali River water chemistry mechanism 


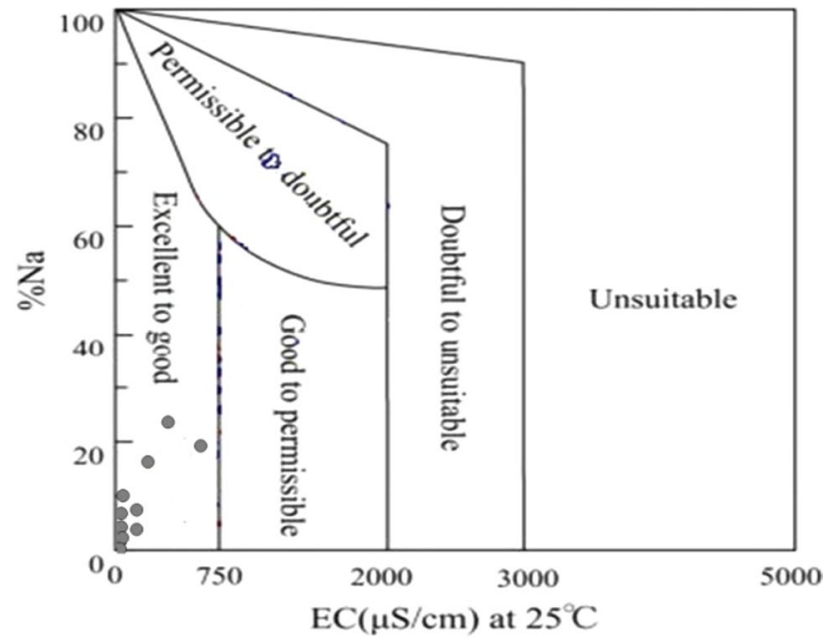

Fig. 5 Wilcox (1955), plot of the rating of Ajali River water samples on conductivity and Na percent basis

10-18), doubtful (18-26) and unsuitable (SAR > 26) (Ravikumar et al. 2011). SAR of Ajali River water showed that only sample $\mathrm{C}$ was unsuitable, sample $\mathrm{A}$ and $\mathrm{B}$ were doubtful while others were good for irrigation. Talabi et al. (2017) reported a range of SAR $(0.15-0.39)$ with an average value of 0.19 which showed River Owan to be excellent in its use as irrigation water.

The United State Laboratory also classified irrigation water based on the sodium absorption ratio and electrical conductivity of water (USSL 1954). USSL classification showed Ajali River water is suitable for irrigation application except for samples from A, B, C, D and E which were below 100 mark of the electrical conductivity (Fig. 6). Sample A fell under medium salinity hazard and high sodium hazard (C2-S4), while sample B fell under low salinity hazard and high sodium hazard (C1-S4). Sample D fell under low salinity hazard and medium sodium salinity hazard (C1-S2), while sample E fell under low salinity hazard and low sodium salinity hazard (C1-S1). These samples (A and B) were collected from the effluent discharge point of the industries, while sample $\mathrm{D}$ and $\mathrm{E}$ are few meters away from the industries effluent discharge point. This showed that the effluents from the beverage industries affect the irrigation suitability of the Ajali River water.

The piper diagram was created to understand the hydrochemical facies (Fig. 7). Seven samples were confined to $\mathrm{SO}_{4}{ }^{*} \mathrm{Cl}-\mathrm{Ca} * \mathrm{Mg}$ water type, which is a typical of gypsum groundwater and mine drainage, three were confined to bicarbonate-calcium water type which is a typical of shallow fresh ground water, and one sample is mixed water type. This shows that alkaline earth metals exceeded alkalis, strong acids exceeded weak acids in seven samples, and four samples recorded weak acids exceeding strong acids. The dominant cations and anions were $\mathrm{Mg}^{2+}, \mathrm{Ca}^{2+}$ and $\mathrm{SO}_{4}{ }^{2-}, \mathrm{HCO}_{3}{ }^{-}+\mathrm{CO}_{3}{ }^{-}$, respectively. The Ajali River water is exposed to the atmosphere, which makes it possible for carbon dioxide to dissolve in the water to form bicarbonate ion, which is in line with the observation of Ajon et al. (2014) in Katsina-ala catchment area of Northern
Fig. 6 United State Laboratory Irrigation water classification diagram based on SAR and conductivity

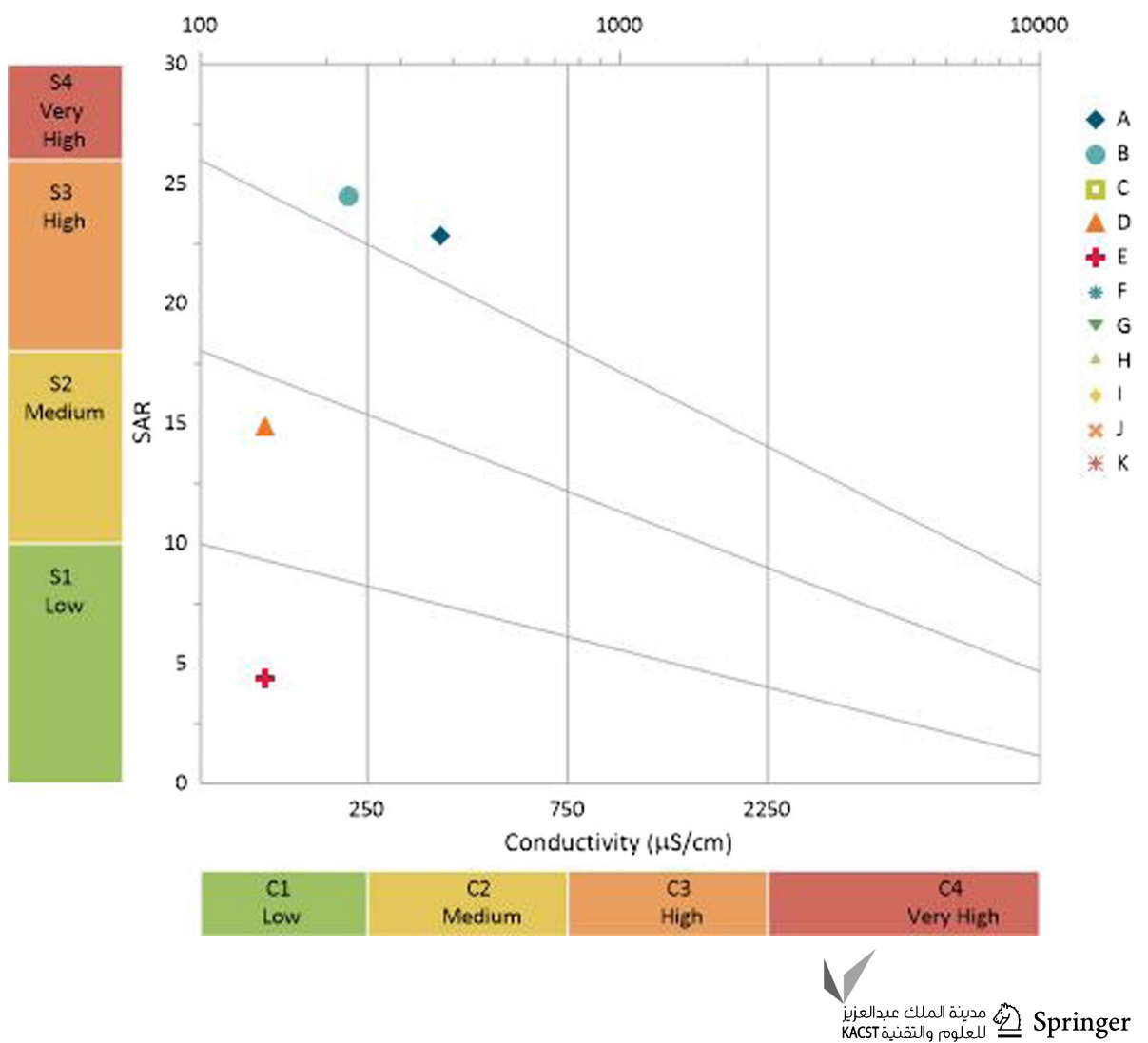


Fig. 7 Piper diagram for Ajali River water

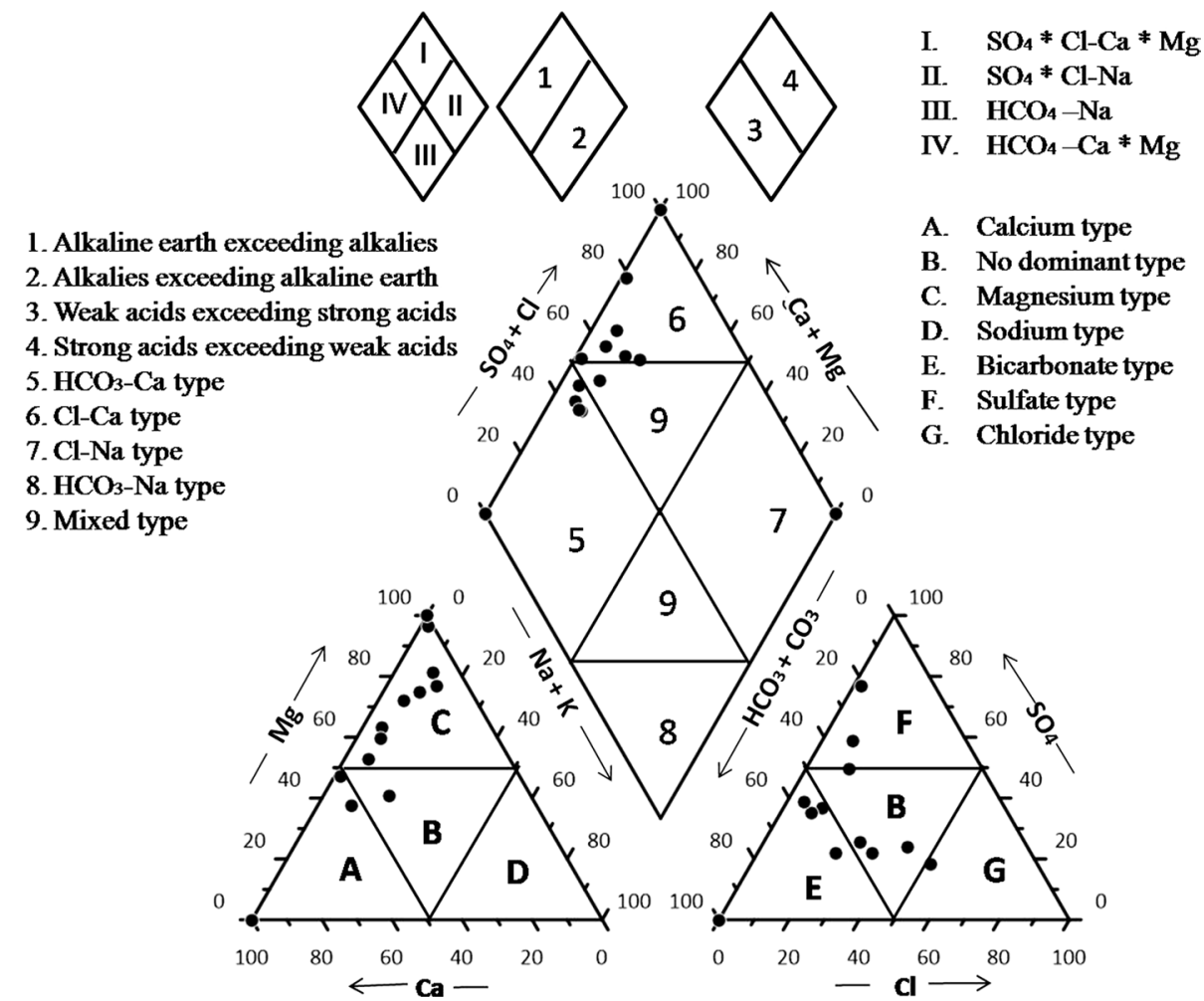

Nigeria. Generally, the hydrochemical facies of Ajali River water were determined by ion exchange, evaporation, and concentration. This is in line with the observation of $\mathrm{Xu}$ et al. (2019). Samples A, B and C, which were collected at the effluent discharge point of the industries, were predicted to be $\mathrm{Na}-\mathrm{Cl}$ water (Table 5). Chloride's main sources into river water are discharge of industrial, municipal waste water, agricultural run-off, and chlorination of public water supplies (Mandal et al. 2019).

The Rockware software was also used to predict the water type, percent difference of anion-cation balance and salinity hazard. The result showed low salinity hazard by all the samples except samples A and $\mathrm{C}$ which were of medium hazard (Table 5). The percent difference of anion-cation balance varied from 2.620 to $71.181 \%$ indicating the anion or cation deficit or surplus. One fundamental law of nature is that in real solutions, the total sum of all the positive charges (cations) must equal the total sum of all negative charges (anions). The software also predicted that 4 samples were of $\mathrm{Na}-\mathrm{Cl}$ water type (A, B, C and F), two $(\mathrm{G}$ and $\mathrm{H})$ were of $\mathrm{Ca}-\mathrm{SO}_{4}$ water type and samples $\mathrm{D}, \mathrm{E}, \mathrm{I}, \mathrm{J}$ and $\mathrm{K}$ were of Na$\mathrm{HCO}_{3}, \mathrm{Ca}-\mathrm{HCO}_{3}, \mathrm{Ca}-\mathrm{SO}_{4}, \mathrm{~K}-\mathrm{SO}_{4}, \mathrm{~K}-\mathrm{Cl}, \mathrm{Ca}-\mathrm{Cl}$, respectively.

\section{Correlation and cluster analysis}

The correlation analysis showed strong positive relationship $(p>0.01)$ between conductivity and TDS (Table 6). Significant relations were also observed between $\mathrm{SO}_{4}{ }^{2-}$, $\mathrm{PO}_{4}{ }^{3-}, \mathrm{NO}_{3}{ }^{-}, \mathrm{Na}^{+}$with TDS and conductivity, and with each other. But at $p>0.05$, there exist a significant relation between $\mathrm{K}^{+}$and TDS, conductivity, $\mathrm{SO}_{4}{ }^{2-}, \mathrm{PO}_{4}{ }^{3-}, \mathrm{NO}_{3}{ }^{-}$, $\mathrm{Na}^{+}, \mathrm{Ca}^{+}, \mathrm{HCO}_{3}{ }^{-}$and conductivity. This is in agreement with the observation of Khan and Jhariya (2018), confirming the observation made by the Hierarchical cluster analysis (Fig. 8).

Table 5 Water type, \% difference of anion-cation balance and salinity hazard as predicted by Rockware software

\begin{tabular}{|c|c|c|c|c|c|c|c|c|c|c|c|}
\hline Parameter & A & B & $\mathrm{C}$ & D & $\mathrm{E}$ & $\mathrm{F}$ & G & $\mathrm{H}$ & I & $\mathrm{J}$ & $\mathrm{K}$ \\
\hline Water type & $\mathrm{Na}-\mathrm{Cl}$ & $\mathrm{Na}-\mathrm{Cl}$ & $\mathrm{Na}-\mathrm{Cl}$ & $\mathrm{Na}-\mathrm{HCO}_{3}$ & $\mathrm{Ca}-\mathrm{HCO}_{3}$ & $\mathrm{Na}-\mathrm{Cl}$ & $\mathrm{Ca}-\mathrm{SO}_{4}$ & $\mathrm{Ca}-\mathrm{SO}_{4}$ & $\mathrm{~K}-\mathrm{SO}_{4}$ & $\mathrm{~K}-\mathrm{Cl}$ & $\mathrm{Ca}-\mathrm{Cl}$ \\
\hline $\begin{array}{l}\% \text { difference of } \\
\text { anion-cation bal- } \\
\text { ance }\end{array}$ & 48.775 & 40.212 & 25.552 & 5.119 & 2.620 & 49.894 & 56.662 & 69.711 & 71.181 & 51.861 & 37.909 \\
\hline Salinity hazard & Medium & Low & Medium & Low & Low & Low & Low & Low & Low & Low & Low \\
\hline
\end{tabular}




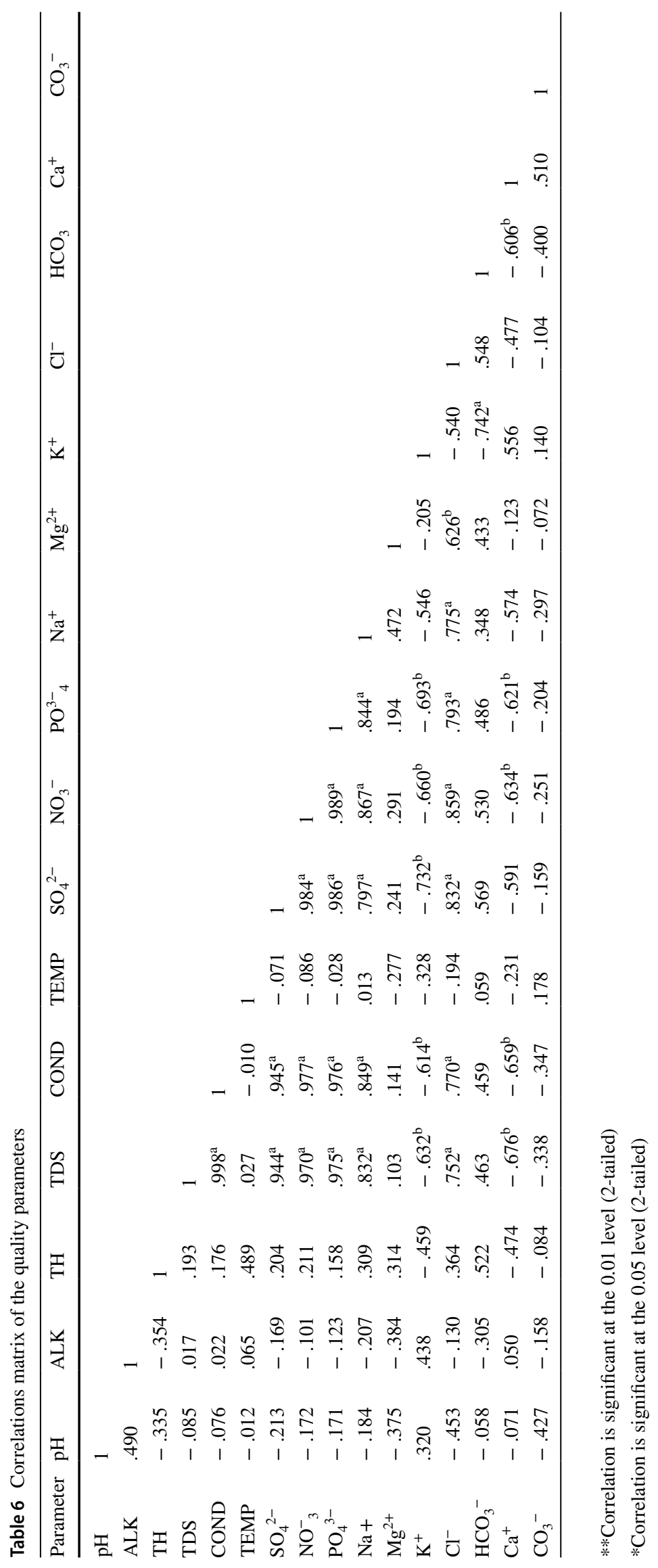


Fig. 8 Hierarchical cluster dendogram of the physicochemical parameters

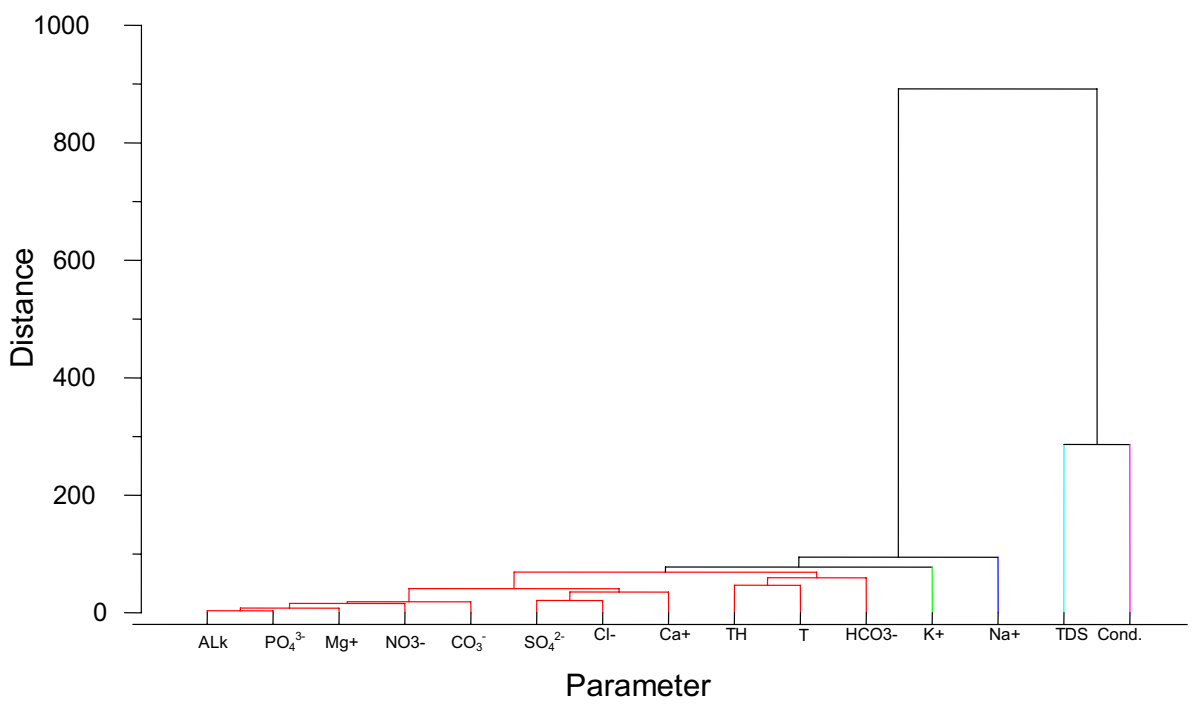

The physicochemical parameters that had similar characteristics were grouped using dendogram Hierarchical cluster (Prakash and Dagaonkar 2011). The parameters were distinctively grouped into two clusters (Fig. 8) of which the TDS and electrical conductivity are in separate group while the rest of the parameters are in one group. The variations in the type of parameter grouped into one cluster could be associated with the differences in sample source, which were affected by the nature of activities around it, and the concentration of the parameters in the water sample.

The cluster showed that TDS and conductivity are not influenced by any other parameters analyzed, while the total hardness (TH) is influenced by $\mathrm{K}^{+}, \mathrm{HCO}_{3}{ }^{-}, \mathrm{Na}^{+}$and temperature $(\mathrm{T})$ of the water sample. Group two, which comprises of all parameters except TDS and conductivity, influenced one another, which was in line with the observation of Radha-Krishnan et al. (2007), Praveen et al. (2008); Oparaocha et al. (2010) and Basamba et al. (2013) which attributed $\mathrm{Ca}$ concentration to anthropogenic activities and natural processes within the aquifers as major sources of water hardiness.

\section{Conclusion}

This study, the water quality suitability using major ion chemistry for irrigation purposes, is a case study of an agricultural area, Udi and Ezeagu, Enugu state, Nigeria. Most of the parameters considered were within the standard by FAO for irrigation application, and the hydrochemical study showed that the water was $\mathrm{HCO}_{3}-\mathrm{Ca}$, $\mathrm{Cl}-\mathrm{Ca}$ and mixed water types with the dominant cations and anion being $\mathrm{Mg}^{2+}, \mathrm{Ca}^{2+}$ and $\mathrm{SO}_{4}{ }^{2-}, \mathrm{HCO}_{3}{ }^{-}+\mathrm{CO}_{3}{ }^{-}$, respectively, suggesting that the water is alkaline with alkaline earth exceeding alkalis. The trend of the cations was $\mathrm{Na}^{+}>\mathrm{K}^{+}>\mathrm{Ca}^{2+}>\mathrm{Mg}^{2+}$ while the anions were $\mathrm{HCO}_{3}{ }^{-}>\mathrm{SO}_{4}{ }^{2-}>\mathrm{Cl}^{-}>\mathrm{NO}_{3}{ }^{-}>\mathrm{CO}_{3}{ }^{-}>\mathrm{PO}_{4}{ }^{3-}$. Most samples were confined to $\mathrm{SO}_{4} * \mathrm{Cl}-\mathrm{Ca} * \mathrm{Mg}$ water type which is typical of gypsum groundwater. Ajali River water was found in the rock dominance zone implying that weathering of rock by the water and leaching are the main processes affecting the water chemistry. With exception to the samples collected around the effluent discharge points of the industries, all the irrigation assessment criteria (PI, SSP, MAR, SAR, CAI, KR and RSC) suggested Ajali River water being suitable for irrigation purposes of which CAI indicated an ion exchange taking place in the between the water and rock.

Funding The authors did not receive any funding.

\section{Declaration}

Conflict of interest The authors declare that there are no conflicts of interest.

Open Access This article is licensed under a Creative Commons Attribution 4.0 International License, which permits use, sharing, adaptation, distribution and reproduction in any medium or format, as long as you give appropriate credit to the original author(s) and the source, provide a link to the Creative Commons licence, and indicate if changes were made. The images or other third party material in this article are included in the article's Creative Commons licence, unless indicated otherwise in a credit line to the material. If material is not included in the article's Creative Commons licence and your intended use is not permitted by statutory regulation or exceeds the permitted use, you will need to obtain permission directly from the copyright holder. To view a copy of this licence, visit http://creativecommons.org/licenses/by/4.0/. 


\section{References}

Ajon AT, Utsev JT, Nnaji CC (2014) Physicochemical quality of irrigation water in River Katsina-Ala catchment areas of Northern Nigeria. Curr World Environ J 9(2):301-311

Akande SO, Hoffknecht A, Erdtmann BD (1992) Upper cretaceous and tertiary coals from southern Nigeria: composition, rank, depositonal environments and their technological properties. Bull Niger Assoc Pet Explor 7:26-38

Akande SO, Ogunmoyero IB, Petersen HI, Nytoft HP (2007) Source rock evaluation of coals from the Lower Maastrichtian Mamu Formation, SE Nigeria. J Pet Geol 30(4):303-324

Aniebone VO (2014) Chemical and microbiological assessment of surface water samples from Enugu area, Southeastern. Niger Glob J Geol Sci 12:15-20. https://doi.org/10.4314/gjgs.v12i1.2

APHA, American Public Health Association (2005) Standard methods for the examination of water and waste water, 21st edn. APHA, Washington

Appelo A, Postma D (1996) Geochemistry, groundwater and pollution. Balkema, Rotterdam, p 536

Asch F, Dingkuhn M, Miezan K, Doerffling K (2000) Leaf K/ $\mathrm{Na}$ ratio predicts salinity induced yield loss in irrigated rice. Euphytica 113:109-118

Atama CI, Eyo JE, Mgbenka BO (2005) Heavy metals in effluents of two industries in south eastern Nigeria. J Sci Ind Stud $3(4): 11-15$

Bar Y, Apelbaum A, Kafkafi U, Goren R (1997) Relationship between chloride and nitrate and its effect on growth and mineral composition of avocado and citrus plants. J Plant Nutr 20:715-731

Basamba TA, Sekabira K, Kayombo CM, Ssegawa P (2013) Application of factor and cluster analyses in the assessment of sources of contaminants in borehole water in Tanzania. Pollut J Environ Stud 22(2):337-346

Bauder TA, Waskom RM, Davis JG (2014) Irrigation water quality criteria. Colorado State University Extension, Fort Collins

Bernstein L (1980) Salt tolerance of fruit crops. USDA Inf Bul 292:9

Cai W-J, Guo X, Chen C-TA, Dai M, Zhang L, Zhai W, Lohrenz SE, Yin K, Harrison PJ, Wang Y (2008) A comparative overview of weathering intensity and $\mathrm{HCO}_{3}$ flux in the world's major rivers with emphasis on the Changjiang, Huanghe, Zhujiang (Pearl) and Mississippi Rivers. Cont Shelf Res 28:1538-1549. https://doi.org/ 10.1016/j.csr.2007.10.014

Cramer G (2002) Sodium-calcium interactions under salinity stress. In: Lauchli A, Luttge U (eds) Salinity: environment-plants-molecules. Springer, Dordrecht, pp 205-227

Doneen LD (1964) Notes on water quality in agriculture. Department of Water Science and Engineering, University of California, Oakland

Egwuonwu CC, Uzojie AP, Okafor VC, Ezeanya NC, Nwachukwu MU (2012) Evaluation of the effects of industrial wastewater discharge on surface water: a case study of Nigeria Breweries PLC. Enugu Greener J Phys Sci 2(3):46-63

Fageria NK, Gheyi HR, Moreira A (2011) Nutrient bioavailability in saltaffected soils. J Plant Nutr 34(7):945-962. https://doi.org/10. 1080/01904167.2011.555578

FAO (1994) Water quality for agriculture. Water quality guidelines, food and agricultural organization. Rome

FAO/UN (2017) Water pollution from agriculture: a global review. Research program on water, land and ecosystem. Published by the Food and Agriculture Organization of the United Nations Rome, 2017 and the International Water Management Institute on behalf of the Water Land and Ecosystems research program Colombo, 2017
Freese RA, Cherry JA (1979) Groundwater. Prentice-Hall, Englewood Cliffs

Fuertes-Mendizábal T, Bastías EI, González-Murua C, González-Moro MG (2020) Nitrogen assimilation in the highly salt- and borontolerant ecotype Zea mays L. Amylacea. Plants 9:322. https://doi. org/10.3390/plants9030322

Gibbs RJ (1970) Mechanisms controlling world water chemistry. Science 17:1088-1090

Grattan SR, Grieve CM (1999) Salinity-mineral nutrient relations in horticultural crops. Sci Hortic 78:127-157. https://doi.org/10. 2136/sssaj1961.03615995002500010016x

Imo CI, Nwakuba NR, Asoegwu SN, Okereke NAA (2017) Impact of brewery effluents on surface water quality in Nigeria: a review. Chem Res J 2(6):101-113

Lenntech (1998) Carbonate and bicarbonate hazard of irrigation water. https://www.lenntech.com/applications/irrigation/bicarbonate/ bicarbonate-hazard-of-irrigation-water.htm

Li P, Qian H, Wu J, Zhang Y, Zhang H (2013) Major ions chemistry of shaloow groundwater in the Dongsheng coalfield, Ordos Basin, China. Mine Water Environ 32:195-206

Li P, Wu J, Qian H, Zhang Y, Yang N, Jing L, Yu P (2016) Hydrogeochemical characteristics of groundwaterin and around a water irrigated forest in the southeastern edge of the Tengger Desert. Northwest China Expo Health 8:331-348

Mahmoud LM, Dutt M, Vincent CI, Grosser JW (2020) Salinityinduced physiological responses of three putative salt tolerant citrus rootstocks. Horticulturae 6:90. https://doi.org/10.3390/ horticulturae6040090

Mandal SK, Kole DS, Pramanik S, Kole RK (2019) Assessment of river water quality for agricultural irrigation. Int J Environ Sci Technol 16:451-462. https://doi.org/10.1007/s13762-018-1657-3

Michael AM (1992) Irrigation theory and practices. Vikash Publishing house Pvt. Ltd., New Delhi, pp 686-740

Neina D (2019) The role of soil pH in plant nutrition and soil remediation. Appl Environ Soil Sci. https://doi.org/10.1155/2019/5794869

Nweke E (2015) Design and supervision of hydraulic structures for Enugu State NEWMAP. Consultancy assignment between Nest Engineering and NEWMAP Enugu, June 30, 2015

Ogbu KC, Ebenebe CI, Abajue MC (2016) Physico-chemical characteristics of Ama brewery effluent and its receiving Ajali river in Udi, Enugu state. Niger Anim Res Int 13(2):2392-2399

Omer NH (2019) Water quality parameters, water quality—science, assessments and policy, Kevin Summers, IntechOpen. https:// doi.org/10.5772/intechopen.89657. https://www.intechopen.com/ books/water-quality-science-assessments-and-policy/water-quali ty-parameters

Oparaocha ET, Iroegbu OC, Obi RK (2010) Assessment of quality of drinking water sources in the Federal University of Technology, Owerri, Imo state, Nigeria. J Appl Biosci 32:19-24

Prakash MM, Dagaonkar A (2011) Application of cluster analysis to physico-chemical parameters of Munj Sagar Talab, Dhar (Madhya Pradesh, India). Recent Res Sci Technol 3(1):41-50

Praveen M, Saurabh A, and Mudita N (2008) Assessment of physicochemical characteristics and suggested restoration measures for Pushkar Lake Ajmer Rajasthan (India). In: Proceedings of Taal2007: the world lake conference, pp 1518-1529

Radha-Krishnan R, Dharmaraj K, Ranjitha BD (2007) A comparative study on the physicochemical and bacterial analysis of drinking, borewell and sewage water in the three different places of Svakasi. J Environ Biol 28(1):105-113

Raghunath HM (1987) Groundwater. Wiley Eastern Ltd., New Delhi, pp 344-369

Raju NJ (2007) Hydrogeochemical parameters for assessment of groundwater quality in the upper Gunjanaeru River basin, Cuddapah District, Andhra Padesh, South India. Environ Geol 52:1067-1074

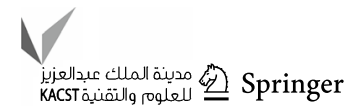


Ravikumar P, Somashekar R, Angami M (2011) Hydrochemistry and evaluation of groundwater suitability for irrigation and drinking purposes in the Markandeya River basin, Belgium District, Karnataka State India. Environ Monit Assess 173:459-487

Rozeff N (1995) Sugarcane and salinity-a review paper. Sugarcane $5: 8-19$

Salifu M, Aidoo F, Hayford MS, Adomako D, Asare E (2017) Evaluating the suitability of groundwater for irrigational purposes in some selected districts of the Upper West Region of Ghana. Appl Water Sci 7:653-662. https://doi.org/10.1007/s13201-015-0277-Z

Shabala S, Cuin TA (2008) Potassium transport and plant salt tolerance. Physiol Plant 133:651-669

Singh P, Tiwari AK, Singh PK (2014) Hydrochemical characteristics and quality assessment of groundwater of Ranchi Township Area, Jharkhand, India. Curr World Environ 9(3):804-813

Sonneveld C, Voogt W (2009) Plant nutrition of greenhouse crops. Springer, New York

Tahmasebi P, Mahmudy-Gharaie MH, Ghassemzadeh F, Karouyeh AK (2018) Assessment of groundwater suitability for irrigation in a gold mine surrounding area. NE Iran Environ Earth Sci 77:766

Tucker BB, Kurtz LT (1961) Calcium and magnesium determinations by EDTA titrations
USSL (1954) Diagnosis and improvement of saline and alkaline soils. Agriculture handbook no. 60 USDA, pp 160

Wilcox LV (1955) Classification and use of irrigation water. USDA, Circular, Washington, p 969

Wilcox LV (1958) Determining the quality of irrigation water. Agric Inf Bull 197:1-6

Wu J, Li P, Qian H (2015) Hydrochemical characterization of drinking groundwater with special reference to fluoride in an arid area of China and the control of aquifer leakage on its concentrations. Environ Earth Sci 73:8575-8588

Xu P, Feng W, Qian H, Zhang Q (2019) Hydrogeochemical characterization and irrigation quality assessment of shaloow groundwater in the central-western Guanzhong Basin, China. Int J Environ Res Public Health 16:1492. https://doi.org/10.3390/ijerph16091492

Publisher's Note Springer Nature remains neutral with regard to jurisdictional claims in published maps and institutional affiliations. 